\title{
Mensagem do Editor Passado
}

ARS LONGA, VITA BREVIS

Horacius, 65-8 bc

$\mathbf{N}$ este editorial, despeço-me como editor-chefe da nossa Revista Brasileira de Cardiologia Invasiva (RBCl) depois de dois anos de um trabalho grandemente recompensador. Quando recebi o convite para o honroso cargo de editor-chefe da $\mathrm{RBCl}$, pressenti um enorme, porém transponível, desafio. Na ocasião, com o apoio incondicional da diretoria da $\mathrm{SBHCl}$, nos foi possível, primeiramente, expandir o convite a colegas que compusessem uma nova co-editoria e um corpo editorial nacional e internacional de cardiologistas intervencionistas e clínicos proficientes nas suas respectivas áreas de atuação. A seguir, juntou-se a nós, para assessoria editorial, a Sra. Rosangela Monteiro, profissional dedicada e com vasta experiência na área de publicações de revistas médicas. Desta forma, tínhamos o apoio diretivo e uma nova equipe pujante e motivada no planejamento e execução de metas. Registro, a seguir, as nossas flagrantes dificuldades e êxitos alcançados em todo este processo:

\section{Apresentação gráfica e conteúdo}

Criamos uma nova apresentação de arte gráfica de capa e miolo, novas seções como Imagem \& Intervenção Cardiovascular, Carta ao Editor, Ponto de Vista, Ciência \& Tecnologia, Artigos Especiais, além das de Artigo Original, Editorial, Artigo de Revisão e Relato de Caso existentes até então. Isso tudo com o objetivo de propiciar uma maior participação dos nossos sócios, ampliando o espectro de contribuições. Nos últimos dois anos, passamos a publicar os resumos dos anais do nosso congresso na própria revista. $\mathrm{A} \mathrm{RBCl}$ foi uma das pioneiras em publicação nacional na forma de artigos eletrônicos exclusivos, incluindo a apresentação de vídeos.

\section{Atualização das edições}

O nosso maior desafio era a atualização editorial. Tínhamos a missão de resgatar um atraso de seis edições, além do compromisso da publicação das edições correntes. Era uma corrida contra o tempo! Para isso, houve uma grande mobilização de todo o corpo editorial e contribuições de um grande número de sócios da SBC e $\mathrm{SBHCl}$. Em uma fase inicial, publicamos fascículos temáticos sobre assuntos de grande interesse da comunidade cardiológica e intervencionista. Nos últimos quatro números, priorizamos a publicação de artigos originais, almejando a indexação da revista. No período de dois anos, publicamos 15 fascículos da revista, totalizando 156 artigos contidos nas diversas seções. Foi com grande satisfação que anunciamos, em 2006, a atualização editorial da $\mathrm{RBCl}$. O primeiro grande óbice havia sido transposto.

\section{Sistema de submissão de artigos on-line}

No segundo semestre de 2006, implementamos um sistema eletrônico de submissão de artigos pela Internet, acessível na página da $\mathrm{SBHCl}$ (www.sbhci.org.br). Desta forma, o processo de submissão de artigos, as revisões por pares e todo o processo de editoração tornou-se mais ágil e eficiente, otimizando a qualidade das publicações e reduzindo o tempo desde a submissão pelo autor até a publicação final do artigo.

\section{Indexação na base de dados LILACS/BIREME}

Todo este trabalho, determinado, único, profissional e envolvendo um grande número de colaboradores, cheio de percalços e não menos apaixonante, culminou com a indexação da RBCI na base de dados LILACS/ BIREME, oficialmente anunciada em janeiro de 2007. Esta conquista premia e reconhece, merecidamente, a nossa revista como publicação oficializada de boa qualidade científica. A indexação trará, inexoravelmente, a submissão de novos e mais artigos espontâneos para a revista. Uma segunda, e talvez a mais difícil barreira, foi vencida. Em 2007, a revista completa 15 anos de existência, agora atualizada e indexada.

Desejo sucesso aos novos editores que assumem esta árdua, mas gratificante, tarefa.

\section{Agradecimentos}

Meus mais sinceros agradecimentos à diretoria da $\mathrm{SBHCl}$, que vislumbrou a necessidade premente e a importância associativa do resgate da nossa revista. Aos Drs. Ronaldo Loures Bueno, Valter Correa Lima e Paulo Caramori, pela confiança e apoio irrestrito ao trabalho realizado. À Sra. Rosangela Monteiro, pela nossa amizade, reforçada por todos estes anos difíceis de trabalho; profissional imprescindível em todo este processo e que não mediu esforços para o sucesso e metas atingidas. Aos co-editores, Drs. Luiz Mattos e Pedro Lemos, pelo profissionalismo e dedicação. À Sra. Maria Luiza Mota, pelo trabalho incansável, envolvimento passional e diuturno com a revista. Aos editores convidados, pela proficuidade nos fascículos temáticos. Por fim, agradeço a todos os autores e sócios da $\mathrm{SBHCl}$ e $\mathrm{SBC}$ que contribuíram, direta ou indiretamente, com a publicação de artigos, cartas, casos clínicos e mesmo palavras de incentivo e apoio ao projeto. Peço, finalmente, desculpas se em algum momento não pude, como deveria - adágio inerente às circunstâncias da vida - me dedicar ainda mais à nossa revista.

Vida longa a RBCI!

Meu muito obrigado e um abraço fraternal a todos.

Adriano Caixeta

Editor-chefe da RBCI 10/2004 a 12/2006 